\title{
TRANSLATION HISTORY: AUDIENCES, COLLABORATION AND INTERDISCIPLINARITY
}

\author{
Outi Paloposki \\ outi.paloposki@utu.fi \\ University of Turku
}

\begin{abstract}
Translation history constitutes a huge field of research where methods, theories, research questions and topics vary widely. One important question here is who we write history to (who is our addressee) and what kind of an impact the perceived audience has on the ways of writing history. In the case of academic audiences, an audience often is also a partner in research collaboration. However, there are other audiences outside the academia as well. In this article, I will illustrate the issue of audiences and interdisciplinarity through describing the work done in translation historiography in Finland. There have been scholars and writers from different academic disciplines and orientations and from outside the academia, involved in Finnish historiography. Among the products of this collaboration is the history of translated literature, published as a book in 2007.
\end{abstract}

\section{Resumen}

La historia de la traducción abarca un amplio campo en el que los métodos, teorías, interrogantes y asuntos varían de forma notable. Una de las preguntas fundamentales consiste en establecer para quién escribimos la historia (cuál es el destinatario) y qué tipo de impacto tiene la audiencia supuesta en el modo de escribirla. En el caso de las audiencias de carácter académico, el destinatario es con frecuencia también un copartícipe del esfuerzo investigador. Sin embargo, existen también otras audiencias más allá de la academia. En este artículo, ilustraré la cuestión de las audiencias y la interdisciplinariedad mediante una descripción de la labor llevada a cabo en Finlandia en torno a la historiografía de la traducción. En ella, han colaborado estudiosos y autores procedentes de diversas disciplinas académicas y orientaciones ajenas al mundo académico, todos ellos interesados en la historiografía de Finlandia. Entre los 
productos de esta colaboración se cuenta la historia de la literatura traducida que se publicó en forma de libro en 2007.

Keywords: Interdisciplinarity. Collaboration. Audiences. National histories.

Palabras clave: Interdisciplinariedad. Colaboración. Audiencias. Historias nacionales.

Manuscript received on June 29, 2012 and accepted on September 28, 2012. 


\section{Introduction: on translation history}

There are many ways to do translation history, just as there are many aims behind the activity. Translation history can be written to bring past translators out of oblivion, but history is also written to study a determined period from the point of view of a specific research question such as censorship or literary influences, for example. Whatever the aim behind the process of writing translation history, this history (or histories) is not the half-forgotten, neglected sub-area of study it was claimed to be some time ago - at times it seems that history is filling rather a lot of space within Translation Studies. The on-line Translation Studies Bibliography, which collects information cumulatively, gives 1994 hits for the keyword 'history'; and the BITRA database (which comprises more than 54000 entries) gives as many as 7666 hits (all figures as of $26^{\text {th }}$ October 2012). New calls for papers in historical topics are circulated, new conferences organized at a steady pace.

The activity of translation overlaps to a large extent with cultural and linguistic history. We have colleagues working with similar questions or data in other disciplines. Traditionally, Translation Studies has drawn heavily from other disciplines, but collaboration may also be mutual, or neighbouring disciplines may form an audience for our work. The question of audience - who we write for- is part of the bigger issue of interdisciplinarity. In its Call for papers, the present volume emphasizes the importance knowing the past has for the profession (both translators and academics), whereas another recent CFP focuses on the quest to address academic audiences outside Translation Studies (Rundle, ed., forthcoming). Furthermore, there are audiences outside the academia as well: policymakers, readers and users of translation. The implications of collaboration and audience design have not been thoroughly discussed as yet.

According to Christopher Rundle (2012: 232), translation historians should be reaching out, addressing scholars who share the same historical interest. To my experience, they are already doing so. The present paper aims at deepening the understanding of different kinds of translation history, their audiences and their uses by way of discussing the present state of the field 
in general and by introducing the history work done in Finland as a kind of a case study. It is an obviously restricted view, but one which hopefully sheds light on the underlying premises of writing history and disseminating research results for a wider audience. It may also be interesting for researchers elsewhere to know what kind of a role Translation Studies has in one particular location: if useful hints are gained, good; if some obvious pitfalls or problems can be avoided elsewhere, better.

In Finland, translation history has been written from different vantage points and within different academic disciplines (and also from outside the academia). Translation Studies researchers have worked together, alone, or in collaboration with historians, linguists and literary scholars. There have been coordinated projects where scholars from different disciplines have participated in the design, carrying out and writing up the research results, among them, the 1300-page history of translation into Finnish. Findings have been published and reviewed in a variety of research and popular journals and newspapers, presentations have been given in academic conferences, at book fairs, in libraries and reading clubs. Intended audiences have included fellow Translation Studies scholars, researchers from other disciplines, and readers and book buyers. Obviously, fields such as the publishing industry have an interest in the research results as well, especially in a country like Finland, where about half of the published literature consists of translations. In the case of non-fiction, the share of translations is even bigger.

The article proceeds as follows: after this brief introduction, the second section discusses different ways of doing translation history in general. The third section focuses on the issue of interdisciplinarity and audiences in Translation Studies. The fourth section, then, provides an account of historical research into translations within one geographical area, that of Finland, with the purpose of illustrating the different starting points and their outcomes. The main focus will be on the history of translated literature into Finnish, published as a two-volume book in 2007 (Riikonen, Kovala, Kujamäki \& Paloposki, eds.), but other history projects and Finnish translation history in general will also be touched upon. The aim of the case study (and this article) is meta-theoretical and methodological: by bringing up and discussing different ways of doing translation research and highlighting one particular project, I hope to shed light on some questions in research design. These questions concern aims, audiences and collaboration. 


\section{Different translation histories}

\subsection{Translations as data for other disciplines}

Even before Translation Studies — and before a Translation Studies audience was in existence- historical translations provided the bulk of data in much of what we now often call neighbouring disciplines. There have been periods in literary, linguistic and cultural history during which many or most of the existing texts were translations. These texts have been studied from a multitude of points of view in varying disciplines; but there have also been people within these disciplines who have paid attention to the fact that despite their significance, translations were not studied as a phenomenon on their own. Historical translations have, for the most part of translation history, been what Rundle (2012: 239) wants them to be: data to add our understanding on various historical phenomena.

\subsection{The figure of the translator}

From very early on, one of the recurring themes has been the people behind the work, the translators. The emphasis on the profession has been a constant in the research interests of the International Federation of Translators, FIT, which set up a history committee in the 1960s with the aim of increasing knowledge about the profession. As a translators' organization FIT was, naturally, interested in a history of translators, and in its Fourth World Congress in Dubrovnik in 1963 it was "unanimously agreed that a comprehensive history of translation should be written" (Delisle \& Woodsworth 1995: 1). Among the results of the work of the FIT history committee are the volumes edited and written by Jean Delisle and Judith Woodsworth on translators in history and translator profiles $(1995,2002)$. Here, the profession attempts at enhancing its visibility by pointing out the often strategic and decisive role of translators in different political, religious, cultural and literary processes in different parts of the world and at different times, but it also passes on to future generations of translators and translation scholars an image of the identity of translators as crucial agents. Even if the idea of a global translation history may today sound like an impossible task, there are partial histories focusing on different aspects of translation and translators. The interest in translators, as agents, seems to have become stronger as of lately.

Translator history has been a main concern for Anthony Pym, whose call for a history of translators (1998) also provided translation scholars and students with a rich methodological toolkit of translation historiography. The emphasis on translators, argues Pym (2009: 31-36), prevents us from 
the pitfall of the particular binarism of Translation Studies, that of seeing things in a binary scheme of source/target: studying translators allows us to see the movement across space. It will also let researchers see what has been marginalized and study contradictions and negotiations, not just the finished translations. Translators as agents in history have been researched also in, for example, the collections edited by John Milton and Paul Bandia (2009) and Tuija Kinnunen and Kaisa Koskinen (2010). The first collection focuses on cultural innovation, change, and power; the second on translators' networks and roles.

\subsection{History as generator of ideas}

History and historical case studies also function as a generator of ideas and concepts that can then be applied to present-day data. Most of the well-known Western translation theorists have worked at least partly with historical data: many of the notions we now are familiar with and may use in interpreting modern-day data have sprung from historical study. 'Invisibility', 'foreignization' and 'domestication' (as in Lawrence Venuti, 1995); 'grandes traductions' (Antoine Berman 1990), 'translation norms' (Gideon Toury 1995), 'manipulation' (Theo Hermans' early work on translation paratexts, 1985), Douglas Robinson's idea of "sway" which he tests on historical cases (2011); 'patronage', 'rewriting' and 'refraction' (André Lefevere 1992), 'metonymy' (Maria Tymoczko 1999) are but a few examples; the ever-continuing debates about the notions of fidelity, literalness, imitation, etc., have their roots in translation history. Historical cases may also be used to challenge present-day data, to function as 'test cases' ("the arbitrary example" like the Irish epic Táin Bó Cúailnge and its translations into English for Maria Tymoczko, see 1999: 33). In the latter case, history could even be seen to take on an instrumental role (see, however, Adamo 2006: 91).

\subsection{Topic-focused histories}

Not just specific notions but also a number of topics in Translation Studies are such that their study has been, if not largely, at least to great extent, based on historical material. These fields of research may focus on a specific topic or phenomenon, such as censorship (see, e.g., the various publications of such authors as Sturge, Rundle, O'Sullivan and Merkle and the collections edited by Ó Cuilleanáin et al in 2008, Wolf et al in 2010 and Asimakoulos \& Rogers in 2011) or the work of a certain author in translation. The amount of scholarly study done on historical Shakespeare translations alone is daunting. 
Retranslations are, almost by definition, an area where historical data come into play. It is also a topic which interests many different audiences (see section 4.3).

\subsection{Compilations and regional histories}

A relatively new feature of the past decade, the compilation of national or language-based histories of translation have often been (and are still being) produced as collaborative efforts in different parts of the world. The Oxford History of Literary Translation in English has appeared in four volumes during the first decade of the new Millennium (the fifth volume is forthcoming) and Encyclopedia of Literary Translation into English was published in 2000. In France, there is an extensive project of translation history into French since the $15^{\text {th }}$ century (see http://ifverso.fr/fr/content/cinq-siecles-de-traductionsune-histoire-renversante-de-la-langue-francaise-0). The first volume is to appear in the autumn of 2012. Historia de la traducción en España (Lafarga \& Pegenaute 2004) and a number of other works addressing Hispanic translation history have been compiled. In Finland, the two-volume translation history appeared in 2007. This book, focusing on literary translations, will soon have a sequel dedicated to translations of non-fiction into Finnish (Paloposki \& Riikonen, forthcoming in 2013). Swedish translation scholars are producing a website with profiles of Swedish translators, focusing on the translating agent ("Swedish Translator Lexicon", http://www.oversattarlexikon.se/); in Ireland, there is a similar project but focusing on the translators of Irish literature into other languages (http://www.dcu.ie/ ctts/). The Estonian history of translation is taking shape and will provide interesting insights into the complicated literary and translation scene of the centuries of Estonian history of literary development, independence, Soviet domination and new independence. In Germany, the scholars working in collaboration in the Göttingen project in translation history have produced a massive output of translation historiography focusing on a number of special topics. There are also several separate volumes of translation history written in Brazil (see Wyler 2005).

Teamwork might seem the ideal way to capture a nation's or linguistic area's translation history in all its depth and width, but there are also some very extensive histories along the lines of geographical or linguistic areas that have been produced almost single-handedly; for example the Hispanic translation history by Anthony Pym (2000).

There are extensive volumes and research projects focusing on a specific period such as the Middle Ages (for example the collections edited by Ellis, by Beer and by Contamine). A history of the Habsburg Monarchy translators 
has just appeared by Michaela Wolf (2012), and the activities of the Turkish Translation Bureau during the mid- $20^{\text {th }}$ century have attracted scholarly attention (see, e.g., Tahir Gürçağlar 2008).

\subsection{Methodology and theory in translation history}

Methodological reflections appear in books and articles on historical topics (sometimes clearly spelled out, sometimes they have to be inferred); they have been edited into practical guidelines (as in Pym 1998), and they have been addressed recently in a number of publications focusing specially on methodology and/or theory in translation history. There have been two special issues of Meta $(2004,2005)$ on history; the journal Translation Studies has just come up with a special issue on methodology in historical studies, and there is a special issue in translation history forthcoming in The Translator. Blank spaces yet to be covered in translation history have been pointed out by Julio César Santoyo (2006). The connection between theory and methodology has been discussed by Simeoni (2003: 191, 194), who compared the sociological theory-driven way of doing research with the historian's case-based study, in an effort to build a framework that would accommodate both methods. In the collection edited by Bastin and Bandia (2006) there are several articles where the link between theory and methodology is made clear. It is clearly of interest to translation scholars what kind of translation history is being written, how, and with what theoretical and methodological underpinnings.

Apart from the 'big' questions concerning our theoretical underpinnings and their influence on methodology, it is important to discuss smaller-scale methodological choices. Research training is one obvious field where methodology needs to be addressed; criteria for thesis examination, publishing and peer reviewing are other areas. Writing for different audiences and doing interdisciplinary research also require methodological reflection. The implications of audience design and collaboration patterns will be discussed next.

\section{Interdisciplinarity and audiences in translation history}

Interdisciplinarity and the question of audiences are not new topics in Translation Studies. Patterns of interdisciplinarity have been discussed by e.g. Gile (2006) and Kaindl (2006). To study the extent and orientation of interdisciplinary exchanges in Translation Studies, Gile (2006) has proposed and put to test a scientometric analysis of citations, with a pilot study consisting of 32 articles in a collection published in 2000. The results point towards what Kaindl (2006: 87-89) calls 'importing interdisciplinarity'. This is roughly an early 
stage of disciplinary integration where most of the interdisciplinary borrowing, be it in the form of methods, theories, findings, or contextual literature, is unidirectional. A second stage would consist of planned cooperation where the insights gained by the different disciplinary partners all contribute to the overall findings (Kaindl's 'mutual interdisciplinarity', 2006: 87-89). I will use this sketch later in my description of the historical studies on translations in Finland; I am also drawing on my own experience of different ways of carrying out interdisciplinary research (further elaborated in Paloposki 2006).

Another distinction observed by Kaindl (2006: 90) is the one between two points of departure for the study of translations. Researchers in Translation Studies are interested in translational phenomena, while other disciplines' interest in translations is to shed light on their respective foci of attention. This encapsulates what was said earlier in the present article on the development of historical research in translation (see section 2.1); it also coincides to a large extent with Rundle's $(2011,2012)$ distinction between what history can tell us about translations or what translations can tell us about history (albeit without Rundle's explicit quest for the latter). Within Translation Studies, the calls for more mutual interdisciplinarity have indeed stressed the discipline's need to export theories and ideas and not just translations as raw data for other disciplines. Rundle's contention that translations matter to history may signal a step back to the 'translations-as-data' phase, but perhaps it can also be seen as a positive sign of a general welcoming attitude in other areas towards translations. Signs and proof have, however, been coming in that other disciplines do have an interest in Translation Studies; that they do appreciate TS findings, and that Translation Studies' point of view can be fruitful for them. More about this in section 4, where the Finnish translation history will be addressed in further detail.

'Mutual interdisciplinarity' involves thus researchers in two or more fields, and these fields also constitute an audience for the research results. Audiences and collaboration partners thus overlap in some sense. In addition to scholarly audiences, however, there are other audiences to be addressed as well. Anthony Pym, in his Method in Translation History, expresses an explicit wish:

Translation history can be a source of ideas and data for the political or sociological study of international relations; it might have more than a few words to say in the development of language policies; its models should be able to address the increasing internationalization of audiovisual culture; it has a great deal to contribute to the general history of literature and of ideas... (Pym 1998: vii) 
The question of audiences concerns thus not just the academic community. The issues addressed in translation history have relevance both for the TS community at large and for other academic and policy-making audiences, including readers, the consumers of translations. Within Translation Studies, the desire to write translation history is not because of an alleged belief in an existing organic unity of translations (as Rundle takes translation historians to believe; 2012: 236), but because translations have the potential for influencing cultural and political history and wielding power, and awareness of this potential and its study in the actual historical circumstances does make sense: not just policy-makers and planners, administrators and potential users of translations, but also the educators and trainers may find use for these research results. In academic curricula, we need an understanding of the wide range of issues where translation is important or instrumental; even school curricula would benefit from such knowledge. Furthermore, the reading public is interested in translated literature: people not only buy and borrow books, they also participate in discussions on translated literature and the history of translations on websites and journals on reading and literature. This is an audience that is not often mentioned when research results are being discussed, but it is an increasingly active audience.

Whereas for Rundle (2011), audiences seem to be largely equated with research partners, I wish to make a distinction between 'audience' and 'research community', if only to spell out the different roles a researcher may have in addressing an audience and in doing actual research in collaboration with scholars from different academic fields. This is important for the later discussion of how to project research results into the community. However, as can be inferred from the above, these two concepts, audience and research community, can and do overlap to some extent, with audience being the wider of the two concepts.

Other reasons have been proposed for projecting our research results towards other academic fields: Gile (2009) suggests that the quality of TS research might benefit from being submitted for publication in academic journals outside TS, because of stricter refereeing practices (and specific knowledge on the topic in question). While quality is not explicitly the point made in Rundle (2012), there is an underlying current of criticism towards historical Translation Studies. Translation history is largely equated with a very specific methodology related to Descriptive Translation Studies in Rundle (2012: 234-235): the criticism towards DTS methodologies in the context of translation history seems to imply that the only aim of translation historians thus far has been to establish "patterns of behaviour that are scientifically and 
quantitatively constructed as norms using abstracted empirical data, with the aim of contributing to a universal history of translation or an overall theory of translation" (Rundle 2012: 233; for a critical discussion of the same project but from a different angle see also Pym 2009: 27-30). This view, however, disregards much of what has been done in translation history, within or without the Descriptive Translation Studies framework, as has already been noted in response papers by Paul St. Pierre (2012), Theo Hermans (2012) and Dirk Delabastita (2012).

I will now turn towards Finnish translations and their history, in an attempt at discussing projects where different audiences have been targeted and where different constellations of researchers and disciplines have had a role to play.

\section{Finnish translation history}

\subsection{Translation in Finland}

During the Swedish reign, Finnish had experienced the transition from an oral into a literary language. The foundations for written Finnish were laid in the work of the Finnish reformer Mikael Agricola (1508?-1557), whose production consisted of 2000 pages of text, mainly in translation. This included the New Testament in Finnish (1548). During the Old Finnish period from Agricola to 1809, the total number of printed books in Finnish was less than two hundred titles. These consisted mostly of religious texts (82\% of all published literature), and of legislation. Finnish is one of the languages the orthography and standardization of which were given a boost by the Reformation. A minority language during the Swedish and the Russian reigns and at times a symbol of cultural independence or patriotism, the Finnish language was shaped and developed through translations throughout centuries. The early period of written Finnish was an era when nearly all written text was translated, adapted or compiled from existing (foreign-language) sources. It has been documented and analyzed by a number of scholars from linguistic, literary, theological and historical viewpoints. Translations have, thus, played an important role as the material for a number of different disciplines' research: they have been the kind of input Rundle seeks. In other words, the situation in Finland was much the same as in many other places: translations had been studied in depth and detail, but the significance or scale of the phenomenon of translation remained under-theorized; a point made very clear by Itamar Even-Zohar (1978). 
This is where Translation Studies and its historical branch have a role to play. As Dirk Delabastita (2012: 246) notes in his response to Rundle, even if history seeks the particular and the specific, we have to know what to relate it to:

It surely makes a difference to the historian whether an event is strictly a one-off or if similar events have been observed in analogous or historically proximate circumstances as well. While historical events are always strictly unique, that doesn't mean they are completely random. Their irreducible specificities become visible against the background of recurrent features, while, conversely, the recurrent features stand out against the historical specificities.

Translation history in Finland is thus not just outlining the events and relating them in the domestic context but making connections to phenomena elsewhere, in order to determine what is local and what is general.

\subsection{Study of translations in Finland}

Apart from serving as data for a number of research questions, translations were rather early on studied as legitimate objects by scholars in comparative literature in Finland. Attention was paid to translations and the influences they carried; this happened as early as the 1950s. Literary scholarship was influential also during the 1980s when the University of Jyväskylä organized a series of summer seminars around translations and translating. The topics of the seminars (and of later publications in the seminar series) included such issues as the cultural impact of translations, translators as agents, and world literature in translation. A pilot project was launched into compiling a bibliography of literary translations into Finnish. One of the literary scholars behind these endeavours, Urpo Kovala, later suggested the writing of the history of translation in Finland, a project which started in 2002 and culminated in the publication of the two volumes in 2007 (Riikonen et al). Kovala's own work on the introduction of Anglo-American writers into Finnish and his knowledge of the late $19^{\text {th }}$ century cultural and pragmatic constraints and environments in translation contributed greatly to the project.

One of the first comprehensive accounts of Finland's translation history was written by Jarl Hellemann (1970), the then publishing director of Tammi, one of the five biggest publishing houses in Finland. This long article (nearly 70 pages) was published in a volume of Finnish literary history. Hellemann's long-term interest in translations and work in introducing large numbers of modern fiction writers in Finland plus his keenness to share this inside information contributed to an overall interest in translations in Finland: he has written a number of memoirs focusing on literary figures, authors and 
translators, and reported on publishing decisions not usually made available for research. He was also one of the writers in the history project of 20022007. Another issue studied early on in Finland was children's and young people's literature in translation (Kuivasmäki 1990). The first PhD dissertation on translation history in Finland was Paloposki's (2002).

\subsection{Interdisciplinary projects and translation history in Finland}

I will here concentrate on two research issues I have personally been involved with and which have an interdisciplinary dimension. The first is a project which was advertised and financed as interdisciplinary and where focus was on language; the second is a Translation Studies topic (retranslation) where the research was done within TS but the results have been written and tailored for different audiences.

The first project (2001-2004) focused on standardization and development of written Finnish in the $19^{\text {th }}$ century. The project was funded by the Kone Foundation in Finland, and among the researchers there were linguists (of the Finnish language), historians and translation scholars. The project was initiated by linguists and historians, but translation scholars were welcomed from the very beginning, and all planning was done jointly. The project organized workshops, talks and a book launch; three people did their PhDs within the project; all articles of the book written by the members of the research team were discussed in joint seminars and commented on by all members of the team; new and innovative ways of presenting research results were introduced (for example, instead of a conference presentation, we did a role play featuring the $19^{\text {th }}$ century characters of our research in a linguistics symposium). Input from Translation Studies was greeted and incorporated in the overall findings, and results were published in a number of research papers in different disciplines.

The second project focuses on retranslations. This is work carried out by my fellow colleague Kaisa Koskinen and myself since 2001. Our research has been anchored in Translation Studies, but its results have been very widespread: articles have been published (in addition to international TS audiences) for several different audiences in Finland. These include literary studies, textual scholarship and folklore studies within the academia; newspapers and radio interviews. We have presented our research findings in several different seminars within the humanities, in book fairs and reading clubs. Retranslation is a topic of potential interest for several audiences, and in Finland it has been picked up by newspapers, blogs and discussion sites on the Internet. The most recent audience consisted of folklorists working with the Finnish 
national epic Kalevala: its translations into other languages have been studied from the point of view of narratives, nation-building, literary influences, translation of verse et cetera, but the problematic of retranslating can shed light to the many issues involved in explaining why certain works may be translated many times over, or how they are translated.

\subsection{History of translations in Finland (Suomennoskirjallisuuden historia I-II)}

There are several problems to be solved when setting out to do a compilation history of translation, even before the issue of interdisciplinarity. One of them is the question of national histories, which brings with it the problematic issue of nationhood. Is it sensible to talk about national boundaries in the first place? The question of national societies has been criticized by Pym (2006: $18,23)$; there are societies that are larger or smaller than nations, and in many cases the translators' work is not defined along the nation-state lines. National boundaries do not coincide with language boundaries either. In Finland, the translating situation is much more complex than merely consisting of translations into Finnish; apart from the second official language of Finland, Swedish, there is translation activity into and from many other languages. Furthermore, Finnish has been used as a target language for translations in places as wide apart in space and orientation as Soviet Karelia and Michigan, USA. These are interesting research areas in their own right, but when starting to plan the book on Finnish translation history (to appear later as Suomennoskirjallisuuden historia I-II), it was decided to draw the boundaries along geographical-linguistic lines. The focus was to be on translations into Finnish within the geographical boundaries of the modern-day nation-state of Finland and its predecessor, the Grand Duchy of Finland. In this way, questions of audience and reception of translated literature could be treated within reasonable limits and many of the constraints and enabling factors (including the educational system and its development, the publishing industry et cetera) would have more explanatory power. However, as Finland as a nation-state has only existed since the year 1917, the translation history of Finland is and has always been closely linked to neighbouring areas.

The two-volume translation history of Finland was published in 2007, and was preceded by nearly six years of preparations and editing. From the very start, it was clear that this was a compilatory project, not a research project. Earlier attempts at securing funding for a research project this size had failed. Any funding that would be granted for the project would go towards compiling and collecting existing information based on previous research on the topic of translations into Finnish; not towards new research. There would 
be gaps in areas that had not been researched; there would be variation in the depth of analysis. However, one of the aims was for the Finnish translation history to provide the basis for future research, collect together all the references to existing information, and try to group and edit the information so that it would be useful for the next generation of research in translation history. And obviously, the compilation did not mean that previous information would be republished as it was but it was rewritten in the light of the overall aims of the project. I will come back to the gaps in the history towards the end of this section.

The two volumes of the translation history of Finland include 120 articles, written by 83 authors. The high number of collaborators in the project stemmed precisely from the perceived lack of previous, coordinated research and from the idea to gather in as much information that was possible on an area that was largely uncharted and widely interdisciplinary. Thus, among the authors of the work there were historians, literary scholars, linguists, philologists, and people specializing in library studies, cultural studies, Arabic and Indian studies, in addition to Translation Studies scholars and translators. Some of the writers were professors, others were PhD students, journalists, authors or independent researchers. There was also one publisher, one mathematician, one theologian and one philosopher among the writers. The biggest group was literary scholars (23 persons), followed by Translation Studies scholars (18). Philologists from different language departments counted for 10 of the writers and there were 9 specialists in the Finnish language. Obviously, these categorizations are not water-tight as many people move from one base to the other. Translation Studies may have come of age in Finland, but many of her forefathers and -mothers come from other disciplines.

One obvious result of such a large and varied team was the variety of the styles of writing and the differences in the approaches, starting points and structure of the articles. Argumentation, data and research questions also varied widely. What was important for one writer could be ignored by someone else writing around a similar topic. For example, the series of articles on translations from specific source languages largely followed the writers' personal styles and traditions of argumentation. This history does not give a smooth, edited version of translation in Finland, but then again, it is perhaps one of the merits of the book that different viewpoints are allowed to exist side by side: it will open up the Pandora's box that is translation in many of its obvious and less obvious ramifications.

Initially the decision to use a large team of collaborators came from the publisher, the Finnish Literature Society, which was committed to publishing 
the book from the start. The Society had just published a new, comprehensive literary history of Finland, and there was general agreement that translations deserved to be studied in more detail. The overall increase in Translation Studies visibility, its academic growth and the increase in numbers of publications in Finland thus coincided with an interest in literary studies to widen the area of research into translations.

The idea of producing a history of translations into Finnish was launched in an open meeting at the Society's premises in 2002. The first meeting was attended by 36 people from different universities, learned societies, associations and from outside the academia. An editorial board and team of four main editors were elected. The four editors were Professor H. K. Riikonen from the then department of Comparative Literature at the University of Helsinki; Urpo Kovala, Assistant Professor in Comparative Literature at the University of Jyväskylä; Professor Pekka Kujamäki from the Savonlinna School of Translation Studies (University of Joensuu) and the writer of this article, then at the Research Institute for the Languages for Finland (but with a schooling in Translation Studies).

The editorial board drafted an outline of the contents, based on the ideas presented in the open meetings, and authors interested in contributing were given the opportunity to produce an abstract of their proposed article. Funding was sought from different sources, most importantly from the Finnish Cultural Foundation, which came forward with enough financing to cover the most immediate costs, the writing and editing fees. There were two assistants, one working for three months at the start of the project in order to produce a bibliography of research done in the history of translations into Finnish, and an editorial assistant to take care of the day-to-day running and practical issues of the project for three years. The task of the latter was of considerable importance because of the large number of collaborators; in the end, the project lasted for longer than was expected due to a number of delays in the production of the articles, and the funding came to an end long before the project was completed. The final editing, proofreading, indexing et cetera was thus done by the editors, including the 'reconstruction' of 21 articles, the final versions of which had mysteriously disappeared from the publisher's computer.

There were thus two factors affecting the final outcome of the book and its general disposition. First, the aforementioned lack of previous, coordinated research on the topic and the need to pool together as much as could be achieved of the earlier separate and partial studies. Translation history had not been written in any systematic manner before. Intentions to set up a 
project in the 1980s had failed for lack of funding. There existed also several studies on topics such as translations into Finnish of a certain author, genre or national literature. Very few analyses had been made of the overall role of translations in the Finnish culture within any specific time frame. The second factor was the limited funding for the project. As has been stated, there was no funding for research purposes, only for the compilation and editing of the volume; the fees for writing were so small that they did not enable anyone to take leave of absence for research purposes. It was thus a stated fact that the forthcoming book would not be the result of new and extensive research but a compilation of information hitherto available and a concerted effort to put to public use all the knowledge that had appeared separately and in diverse publications. Despite the fact that there were no explicit attempts at arriving at new discoveries, many of the authors did embark on new research on their chosen topics in their own time or as part of their other research, thus enriching the contents of the book.

The two volumes of the book gradually evolved into a first part, including a chronological and genre-oriented history of translation into Finnish, and a second part, a thematic one, the idea of which was to address a number of translation specific questions including forays into translations from different languages, specific translation issues such as translation and language (the role of translation in the development of the written language, translating dialects, translating into dialects) and translation criticism. The table of contents underwent a number of changes throughout the whole process of writing and editing the book, with the last articles being commissioned at the very last stages of editing.

Within this framework, the articles included nearly everything and anything from specific translators or translations to genres, odd cases and historical periods. The only kind of an article that is lacking from the book, causing some criticism, is author profiles: chapters or articles on specific foreign authors in Finnish translation. The decision was rather unanimous, though: there was no space. Obviously, authors do come up all along; but the only author who got a short article in the book is actually the Finnish author Tove Jansson, who wrote in Swedish and whose tales have been translated into Finnish. The article highlights the bilingual cultural environment of Finland; an issue that comes up in other articles as well.

The first part of the book had an extensive background article into Finnish as a translated language during 1544-1809 and the translations written during that time. The division into chronological periods follows the division, generally adapted to divide the development of the Finnish literary language 
into Old Finnish, Early Modern Finnish and Modern Finnish, which respond roughly to external, political or religious, turning points in Finland's history. The period of 'Old Finnish' lasted from the Reformation down to the annexation of Finland to Russia in 1809; 'Early Modern Finnish' up to the end of the Russian rule (1917); and 'Modern Finnish' is considered to have started some time before independence.

The foundation article discussing the Finnish language and literature, written by the Finnish linguist and researcher into that specific period in the history of the Finnish language, Dr. Kaisa Häkkinen, was complemented with a number of other experts' articles on the translation of legal texts, oral poetry, the Bible, hymns and religious texts. The phenomena studied included the birth of the literary culture and written language, spreading and adaptation of genre conventions, dissemination of ideas and knowledge.

The period of 'Early Modern Finnish' coincides with the political changes of domination - from under Swedish rule to Russian rule to independence. Intertwined in many ways with the political developments, the history of translation into Finnish during this period also reveals the many contextual bindings to educational system, literacy, the birth of modern publishing industry, the channels and routes to large-sale bookselling, library systems and other factors that facilitated the circulation of translations by enabling the audience to exist, in the first place, and to receive the translations, in the second place. Attention was paid to the acquisition of language skills and to the working methods (collaborative translation and translators' aids, among other things) in addition to textual analyses of translations. Selection processes of literature to be translated, censorship and the translation of genres such as drama and children's literature were also addressed.

The first volume goes on to introduce the changes in the literary and translation establishment in the $20^{\text {th }}$ century, the rise of the popular culture (and the counter-attacks to curb its spreading). The internationalization of the book publishing trade, war-time translations, the influence of modernism and an overview of the translation of non-fiction literature are among the topics covered in this part of the book.

One of the aims of the book was to delve deeper into translator histories, along the lines of Pym's quest for focusing on translators. There are thus 24 translator portraits (and one portrait profiling a pseudonym used by several translators). The idea was, at least partly, to bring into light the often forgotten translators and grant them some visibility. However, because of the lack of previous research on translators, it is evident from the result that no invisible translators actually came to light: all of the portrayed translators (many 
of them authors) were famous in their own time, and many are still very well-known. The result is thus not what Georges Bastin (2006: 121) desired: "[...] eschew the 'great names' [...] and seek out the throngs of neglected translators". The 12 translators, portrayed in the first volume, were all multiprofessional (see Pym 1998: 161-166). They were authors in their own right, journalists, professors, linguists or teachers; and very visible ones as such. What is still lacking is the history of the invisible translators: anonymous translators, translators whose work soon disappeared from sight, those who did hack work, those who did only one translation in all their lives (and there are many of those); all those that were not famous on other accounts. For this kind of a history much remains to be done. The shadowy existence of invisible translators can hopefully now be sketched on the basis of new data that have come to light in the publishing houses' archives, for example.

The second volume is meant to provide information on specific issues in translation history: the overall influences and literary currents across times in the light of statistics, the translation flows from different language areas (the so-called "world map" of translated literature), gaps in translated literature, norms and strategies, translation and language, and translation criticism.

Many of the authors did careful and extensive research into their chosen topics, despite time constraints, thus enlarging our views and understanding on a number of issues. For example, the trends and foci of translators of French into Finnish were charted in detail, paying attention to retranslations, resulting in a particularly insightful article. Another article reads closely the remarks made by the developers of the Finnish written language in the magazine Virittäjä, the Finnish language journal, at the turn of the $19^{\text {th }}$ and $20^{\text {th }}$ centuries, and offers valuable insights into the role of translators: at no other point in the history of the Finnish language has there been such attention paid in academic journals to the language of translations. Translators were cast in the role of guardians of pure Finnish and harshly cricitized if they failed in the eyes of the linguists - but they were also praised at times. The article also highlights some of the issues that have been debated in Translation Studies recently, for example language attitudes, the 'translatedness' of language and its features - early antecedents of the discussion of translation universals.

Also some peculiarities were discussed, such as rare phenomena which were thought to shed light on the issue of translation and our understanding of it. Thus, for example, the pseudonym Lea Karvonen was profiled as a translator - despite the fact that such a person never existed. If there are pseudo-translations, there are also pseudo-translators or aliases that are used, 
for example, as a 'shield' for well-known translators working on literature they may not want to have their name on.

What has been achieved with this history is 'translation archeology' in the words of Anthony Pym (1998: 1) —outer translation history, as termed by the Göttingen history group-, that is, who were the translators, where they worked, in what conditions, what was translated, from which languages et cetera. Some of the inner translation history has also been discussed: how these translations were made (jointly or alone; word-by-word/ fluent Finnish/ adapting), how they impacted the literary scene in Finland (the birth of the Finnish theatre, modernism, the impact of sci-fi or serialization of children's literature), for example, or why they were translated the way they were, in the first place.

Some general remarks can be made on the project and its contribution to the discussion on interdisciplinarity and methodology in Translation Studies. A big project like this one can never fulfill all the expectations: there are always bound to be topics that are not covered, either because there is not enough basic research done on them or because the expert in the field is either not available for the task, or for some other reason. Thus, for example, there is no article in the book about retranslations, since the research on them has been largely done only after the publishing of the book. The topic is mentioned in several articles, but there is no general discussion in the book about the what's and the why's of retranslation, its scope and forms in Finland. Translators' agency is another topic which would definitely be included if the book were written now, but at the time, there was not enough to draw on to paint a comprehensive picture of translators, their roles, responsibilities, constraints and liberties. Translators' prefaces and footnotes are yet another field that has only been researched more extensively after the publication of the book. All of these topics seem like they should self-evidently be in, but the research had not been done yet.

Methods and data varied and were different in each article: the amount of information available on translations from English was much bigger to start with than for example on translations from French. Some periods have been very well documented from the point of view of written language development; others were very much blank spaces. There had been research into some areas of poetry or drama translation whereas others were totally neglected. In terms of translation archaeology, however, the size of the project was a definitive asset: much more ground has now been covered, many more new sources made available for the work to continue. 
Collaboration also helps to see the bigger picture. The emphasis of historians on the general historical environment and of the constraints of writing history (the limits of existing bibliographies, for example), of literary scholars on writing practices and the fluctuating status and form of the originals, of linguists on the innovations on the form of the language and the negotiating processes in language planning all came to play. Different paradigms, let alone different disciplines cannot be easily forged into one unified whole. The result is a polyphonous work, where in addition to statistical analyses and lists of translated books there are different kinds of illuminating ideas, wholesale surveys, inspiring remarks, essayistic treatises, narratives and a number of points that can be focused on in future research. Interdisciplinary research in an environment like the Finnish translation history project is necessarily carried out in a fairly loose framework. It is a reference work that offers many things to many different kinds of readers: students, researchers, translators, book lovers. At the start of the project, the audience was conceived of as large and diffuse. The writing team ended up being almost as large and diffuse. The project, however, forged out of the mass of details a history which will, hopefully, cover enough ground as to be helpful for future translation historians. At the moment, it is being used as a course book in several Finnish universities, it is constantly being consulted as a reference volume in Master's theses, $\mathrm{PhD}$ theses, literary and cultural history, and it is also widely available in municipal libraries all over Finland. It was reviewed in a number of publications, including the biggest national newspaper in Finland (Helsingin Sanomat), literary, linguistic and history journals, both for academic and general readership. It is recommended by librarians on their web pages and commented on in blogs. It has thus fed onto several fields and even if research itself was not carried out concertedly, the results now live side by side and interact in the reception process. Collaboration, here, meant writing towards a common goal; the aftermath of the book has given birth to new, more collaborative projects of smaller scale. Strictly speaking, the book project was neither 'importing' nor 'mutual' but something in-between, and it has given rise to a new way of interdisciplinary collaboration.

Obviously, this is not the kind of project that Christopher Rundle is advocating: it does not shed light on a particular historical moment or issue. What it does, however, is raise awareness of the variety of the particular moments in history which may profit from a Translation Studies viewpoint. It also shows that you can "exist" in the overlapping worlds of Translation Studies and historical studies: you can write your research results for a different audience they might have originally been intended to. Translation Studies topics evolve 
during their life-time: a research issue which may initially only seem to interest translation people, may end up revealing connections between phenomena traditionally taken to be the province of some other discipline. Take the earlier example of studying retranslations: while the textual profiles of the translations may be the most important research focus at the early stages (and the people interested in the study may consist mostly of translation scholars and other people who read translations), the project may change shape at a later stage with the accrual of new kinds of data: paratexts or review data and data on publishing house practices in manipulating/revising (re)translations lead to new research questions and imply a different methodological framework and different theoretical premises. While the main audience may still be translation studies people, literary scholars may well have a vested interest in reception studies of translated texts, canon formation et cetera. The study now comprises totally new sets of data and starts to reveal a different picture of translated texts, their writers, authorship and the question of agency in general. The findings may then spill out towards book history, history of the publishing industry, and towards more generalized strands of history of nationalism with all its ramifications into literacy, language standardization et cetera. Starting from a purely TS focused topic, the project metamorphoses into a study of interest for many potential readerships. In Finland, this sort of movement from one discipline to the other —addressing a new audiencehas been made easier through the project work on the history of translated literature into Finnish. It has opened up areas of research and common interest between different disciplines and the fact that the scholars now know of each other and of each other's work is not a mere detail. New research is being carried out, peer comments and participation is welcomed across disciplinary borders. Furthermore, the project has engendered a number of articles in journals that are being read by ordinary readers, which means that the audiences are further enlarged.

\section{Conclusions}

In my paper, I hope to have shown that it is possible to have an alternative (or perhaps a complementary) way of looking at translation history, its aims and the different ways of doing it. I have treated Finnish translation history as a test case, and argued that translation history can be carried out in a widely interdisciplinary effort, and that different audiences can profit from the results of translation history projects. A very strict division into two audiences, which have to be pre-determined before the start of the research, forces previous work on translation history into too narrow a frame and overlooks much 
of what has been done during the past decades. It also disregards the fact that some translation historians have been collaborating all along with their colleagues from neighbouring disciplines. For someone who has been writing translation history in close collaboration with historians, linguists and literary scholars throughout his/her academic career, the two-audience view seems an unnecessarily restrictive view of the practice, process and premises of research.

"Refract" was a word used by the historian E. H. Carr in the early 1960s in his lectures to refer to interpreting in historical research (1978: 22). Twenty years later, André Lefevere (1981: 72) introduced this term into Translation Studies. Translators refract their originals; we, as historians, refract our sources. Translations and sources are alike in that they are never pure; they are work of human actors. Clear divisions and categories might be easier to work with; yet, the overlapping, messy areas may be more interesting as objects of study.

\section{References}

Adamo, Sergia. (2006) "Microhistory of translation." In: Bastin, Georges L. \& Paul Bandia (eds.) 2006. Charting the Future of Translation Studies. Ottawa: Ottawa University Press, pp. 81-100.

BASTIN, Georges L. (2006) "Subjectivity and rigour in translation history: the Latin American case. In: Bastin, Georges L. \& Paul Bandia (eds.) 2006. Charting the Future of Translation Studies. Ottawa: Ottawa University Press, pp.111-129.

BAstin, Georges L. \& Paul BANDiA. (eds.) (2006) Charting the Future of Translation Studies. Ottawa: Ottawa University Press.

BEER, Jeannette. (ed.) (1989) Medieval translators and their craft. Kalamazoo: Medieval Institute Publications.

BERMAN, Antoine. (1990) "La retraduction comme espace de la traduction." Palimpsestes 13:4, pp. 1-7.

CARR, Edward Hallett. (1978) What is History? London, Reading \& Fakenham: Penguin Books.

Contamine, Geneviève. (ed.) (1989) Traduction et traducteurs au moyen âge. Actes du colloque international du CNRS organisè a Paris, Institut de recherche et d'histoire des texts les 26-28 mai 1986. Paris: Éditions du Centre National de la Recherche Scientifique.

Delabastita, Dirk. (2012) "Response [to Christopher Rundle]". Translation Studies 5:2, pp. 246-248.

Delisle, Jean \& Judith WoOdSWORTH (eds.) (1995) Translators through History. Amsterdam \& Philadelphia: John Benjamins. [Les Traducteurs dans l'histoire. Ottawa/Paris: Les Presses de l'Université d'Ottawa/UNESCO, 1996] 
Delisle, Jean. (2002) Portraits de Traductrices. Ottawa: Presses de l'Université d'Ottawa

ELLIS, Roger (ed.) (1991) The Medieval Translator 2. London: Centre for Medieval Studies.

Ellis, Roger; Jocelyn Price; Stephen Metcalf \& Peter Meredith (eds.) (1989) The Medieval Translator. Cambridge: D. S. Brewer.

EVEN-ZOHAR, Itamar. (1978) "The position of translated literature within the literary polysystem." In: Even-Zohar, Itamar (ed.) Papers in Historical Poetics. Tel Aviv: The Porter Institute, pp. 21-28.

Frank, Armin Paul \& Harald KitTEL. (2004) "Der Transferansatz in der Ubersetzungsforschung." In: Frank, Armin Paul \& Horst Turk (eds.) 2004. Die Literarische Ubersetzung in Deutschland. Studien zu ihrer Kulturgeschichte in der Neuzeit. Berlin: Erich Schmidt.

GILE, Daniel. (2006). "L'Interdisciplinarité en traductologie. Une optique scientométrique." In: Kasar, Sündüz Öztürk (ed.) Interdisciplinarity on Translation. Vol. 1. Istanbul: Les Editions Isis, pp. 23-27.

GILE, Daniel. (2009) "Research for training, research for society in Translation Studies." In: Pym, Anthony \& Alexander Perekrestenko (eds.) 2009. Translation Research Projects 2. Tarragona: Intercultural Studies Group, pp. 35-40. Full-text version at: <http://isg.urv.es/publicity/isg/publications/trp_2_2009/ index.htm>

Hellemann, Jarl. (1970) "Suomennoskirjallisuus" [Translated literature into Finnish]. In: Tarkka, Pekka (ed.). Suomen kirjallisuus VIII. Kirjallisuuden lajeja [Finland's literature VIII. Literary genres]. Keuruu: Otava, pp. 418-484.

Hermans, Theo. (1985) "Images of translation: Metaphor and imagery in the Renaissance discours on translation." In: Hermans, Theo (ed.) 1985. The Manipulation of Literature. London: Croom Helm, pp. 103-135.

Hermans, Theo. (2012) "Response [to Christopher Rundle]." Translation Studies 5:2, pp. 242-245.

KAINDL, Klaus. (2006) "Complexity and interdisciplinarity: two key concepts in Translation Studies. In: Kasar, Sündüz Öztürk (ed.) Interdisciplinarity on Translation. Vol. 1. Istanbul: Les Editions Isis, pp. 85-94.

Kinnunen, Tuija \& Kaisa Koskinen (eds.) (2010) Translators' Agency. Tampere Studies in Language, Translation and Culture. Series B4. Tampere: Tampere University Press, pp. 1-22. Full-text version at: <http://tampub.uta.fi/ handle/10024/65639>

KUIVASMÄKI, Riitta. (1990) Siiwollisuuden tuntoa ja ylewätä kauneuden mieltä. Suomenkielinen nuorisokirjallisuus 1851-99. [A chaste mind with a noble longing for beauty. Finnish-language children's literature 1851-1899]. Jyväskylä Studies in the Arts 34. Jyväskylä: University of Jyväskylä. 
Lafarga, Francisco \& Luis Pegenaute (eds.) (2004) La historia de la traducción en España. Salamanca: Ambos Mundos.

LEFEVERE, André. (1981) "Towards an Integrated Theory." Bulletin: Midwest MLA $14: 1$.

LEFEVERE, André. (1992). Translation, Rewriting and the Manipulation of Literary Fame. London \& New York: Routledge.

Milton, John \& Paul BAndiA. (eds.) (2009) Agents of Translation. Amsterdam \& Philadelphia: John Benjamins.

Ó Cuilleanáin, Cormac; Eiléan Ní ChuilleanÁin \& David Parris (eds.) (2008) Translation and Censorship: Patterns of Communication and Interference. Dublin: Four Courts Press.

O'Sullivan, Carol. (2012) "Introduction: Rethinking methods in translation history." Translation Studies 5:2, pp. 131-138.

PALOPOSKI, Outi. (2002) Variation in Translation. Unpublished PhD thesis, University of Helsinki.

PALOPOSKI, Outi. (2006) "Translation, history and interdisciplinarity." In: Kasar, Sündüz Öztürk (ed.) Interdisciplinarity on Translation. Vol. 1. Istanbul: Les Editions Isis, pp. 291-300.

PALOPOSKI, Outi \& H. K. RIIKONEN (eds.) (forthcoming in 2013). Tietokirjallisuuden suomennosten historia [History of non-fiction translations into Finnish]. Helsinki: SKS.

PyM, Anthony. (1998) Method in Translation History. Manchester: St. Jerome.

PYM, Anthony. (2000) Negotiating the Frontier. Manchester: St. Jerome.

PyM, Anthony. (2006) "Introduction. On the social and the cultural in Translation Studies." In: Pym, Anthony; Miriam Shlesinger \& Zuzana Jettmarová (eds.) Sociocultural Aspects of Translating and Interpreting, pp. 1-25.

PyM, Anthony. (2009) Humanizing Translation History. Hermes 42, pp. 23-48.

Riıkonen, H. K.; Urpo Kovala; Pekka KujamäKi \& Outi Paloposki (eds.) (2007) Suomennoskirjallisuuden historia I-II [History of translated literature into Finnish]. Helsinki: SKS.

Robinson, Douglas. (2011) Translation and the Problem of Sway. Amsterdam \& Philadelphia: John Benjamins.

RundLE, Christopher. (2011) "History through a translation perspective." In: Chalvin, Antoine; Anne Lange \& Daniele Monticelli (eds.) Between Cultures and Texts - Entre les cultures et les textes. Frankfurt am Main, Berlin, Bern, Bruxelles, New York, Oxford, Wien: Peter Lang, pp. 33-43.

RundLE, Christopher. (2012) "Translation as an approach to history." Translation Studies 5:2, pp. 232-240.

RundLE, Christopher. (ed.) (forthcoming) Special Issue of The Translator. 
SANTOYO, Julio-César. 2006. "Blank Spaces in the History of Translation." In: Bastin, Georges \& Paul Bandia (eds.) Charting the Future of Translation History. Ottawa: University of Ottawa Press, pp. 11-43.

SimeOni, Daniel. (2007) "Between sociology and history. Method in context and in practice." In: Wolf, Michaela \& Alexandra Fukari (eds.) Constructing a Sociology of Translation. Amsterdam \& Philadelphia: John Benjamins, pp. 187-204.

St. Pierre, Paul. (2012). "Response [to Christopher Rundle]." Translation Studies 5:2, pp. 240-242.

TAHIR GÜRÇAĞLAR, Şehnaz. (2008) The Politics and Poetics of Translation in Turkey, 1923-1960. Amsterdam \& New York: Rodopi.

TOURY, Gideon. (1995) Descriptive Translation Studies and Beyond. Amsterdam \& Philadelphia: John Benjamins.

TymoczKo, Maria. (1999) Translation in a Postcolonial Context. Manchester: St. Jerome.

Venuti, Lawrence. (1995) The Invisibility of the Translator. A History of Translation. London \& New York: Routledge.

Wolf, Michaela. (2012) Die vielsprachige Seele Kakaniens. Wien: Böhlau.

Wolf, Michaela; Luc van Doorslaer; Denise Merkle \& Carol O'Sullivan. (eds.) (2010) The Power of the Pen. Translation and Censorship in Nineteenth-Century Europe. Vienna: Lit Verlag.

WYLER, Lia. (2005) "A promising research ground: Translation historiography in Brazil.” Meta 50:3, pp. 851-857. 


\section{BIONOTE / NOTA BIOGRÁFICA}

Outi Paloposki is Professor of English translation at the University of Tur$\mathrm{ku}$ (Finland), School of Languages and Translation Studies. Her PhD thesis (2002) focused on the history of translations in Finland in the early $19^{\text {th }}$ century from the point of view of variation. She has since written on translators' agency, on retranslations, and on the linguistic profiles and role of translations in the changing cultural scene of Finland during the late $19^{\text {th }}$ century and early $20^{\text {th }}$ century. Methodology in Translation Studies, especially historical studies, figures as one of her teaching priorities.

Outi Paloposki es profesora de traducción (inglés) en la Universidad de Turku (Finlandia), en la Escuela de Idiomas y Traductología. Su tesis doctoral (2002) trata sobre la historia de las traducciones en Finlandia durante la primera mitad del siglo XIX desde el punto de vista de la variación. Ha publicado artículos sobre la agencia de los traductores, sobre retraducciones, sobre los perfiles linguísticos de las traducciones y sobre el papel que desempeñaron en la Finlandia del siglo XIX y del siglo XX. Le interesan las cuestiones metodológicas, especialmente en la rama histórica de la traductología. 